\title{
Specialization Impact on Internet Resource Usage: Omani Undergraduate Learner's Perspectives
}

\author{
B. Sriram \\ Faculty and Quality Assurance Officer Sur University College, PO: 440, PC: 411, Sur, Sultanate of Oman \\ Mob: 00968-92186725; \\ Email: srishan11@gmail.com
}

\begin{abstract}
The current educational processes need various tools and technological supports in order to attain the required level of knowledge. The learning processes have been simplified with the help of different resources including internet resources. The usage of internet resources usage depends on the learner's requirements in the field of study. This research had identified the significant impacts of the specialization of the learners on the internet resource usage. Also, the paper identified some specializations that have major influences in using such internet resources in learning processes. The study had been conducted in Omani undergraduate student's environment with respect to selected specializations. The specialization impacts on the frequency of using internet resources, places of searching and purpose of using internet resources in the learning processes were analyzed using conditional probabilities and impacts had been identified with the help of decision tree diagram. The results showed that the students studying Information Technology specialization had greater impact in using internet resources in their learning processes compared to others at undergraduate levels.
\end{abstract}

Index Terms - Internet Resources, Learning Processes, Specialization Impacts, Technology Supports in Learning, Probabilistic Approach.

Abbreviations: I.T. - Information Technology; I.S. Information Systems Acc - Accounting; FB - Finance and Banking; MM - Management \& Marketing; Engn Engineering.

\section{INTRODUCTION}

The technology has developed the various tools and gadgets for educational applications. Teaching and learning processes have drastically changed due to these enhanced tools. Various resources available in the World Wide Web made the educational processes easier than the traditional processes. The learners have easy access to different educational resources available in the net to get their required outcomes. The intended learning outcomes shall be met up to some required extents with the help of these internet resources.

The educators' usage of these internet resources in their educational processes depends on their technology backgrounds and requirements in their course works. The learners' perspectives on these online resource usage depends on various factors such as students' educational requirements, learning environment, motivation, technology knowledge, availability of resources, level of study and specialization which they study. All the countries are improving their Information Communication Technology (ICT) infrastructures to provide optimum facilities to their citizens. In particular, the school education and higher education sectors have been concentrated additionally in order to make the students to be more active learners.

In this paper the impacts of the specialization that the student study on the internet resource usages had been analyzed.. The major factors of internet resources usages have been identified and the impacts of specialization on them had been analyzed. The study was conducted in the Omani Undergraduate environment with selected specializations offered in the particular university. The data collected were analyzed with respect to various perspectives. Probabilistic approach was used to find the impact of the specializations on the factors. The paper proposes a model of impact by the specializations on the internet resource usages by the learners' in their learning processes at undergraduate level.

The purpose study and study background with expected model has been defined next. Section II discusses the literature reviews related to this research. In Section III, the research methodology has been discussed. Various statistical analyses are defined in Section III. The findings and conclusion are discussed in section IV \& V.

\subsection{Purpose of Research}

1. To identify the major factors that influences the Omani learners to use internet resources in their learning processes.

2. To identify the specialization that has major impact on the usage of internet resources in learning processes.

\subsection{Study Background}

The study was conducted among the following specializations: Information Technology (S1), Information Systems (S2), Accounting (S3), Finance \& Banking (S4), Marketing \& Management (S5), Architectural Engineering (S6) and Mechanical Engineering (S7). As the engineering students were either at common foundation level or 1st year common bachelor 
level, it had been considered as a single specialization Engineering (S6). The major factors of internet resource usages were identified as: Frequency of Usage (F1), Place of Search (F2), Purpose of Usage (F3) and Dependency on internet resources (F4). The students studying foundation, diploma and bachelor level of undergraduate study were considered for this research purposes.

\subsection{Expected Impact Model}

Based on the assumptions and considerations, the following impact model had been expected in the Omani leaners' environment. The four factors F1, F2, F3 and F4 were given equal weight in the internet resource usage. The specializations ( $\mathrm{Si}, \mathrm{i}=1$ to 6 ) have been assumed to have equal impact on these four factors. Fig 1 shows the expected impact model.

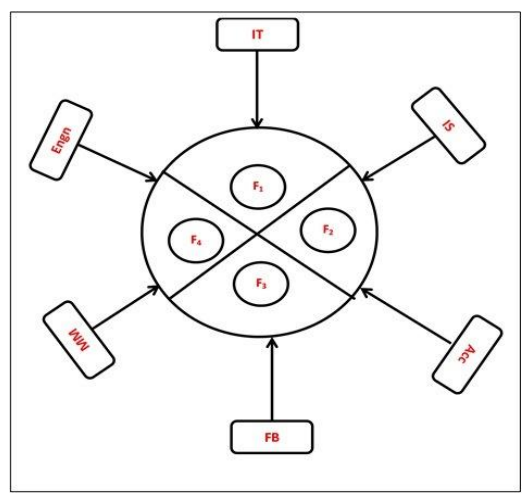

Fig 1: Expected Impact Model

\section{LITERATURE REVIEW}

The researchers had studied about various factors influencing the use of electronic resources in general and specific perspectives such as Postgraduate student's usage [1], adoption of digital resources [2, 3], student's attitude towards usage [4], learning behavior [5] and user satisfaction $[6,7,8,9]$.

The study on impacts of demographic variable on online library resources identified that the internet and e journals were the important source of information. Also, the findings revealed that there was a significant impact of level of study on the utilization of the online resources [10]. The study on various factors influencing the postgraduate students in using electronic information sources identified that the factors influencing the use of electronic information sources by the students vary between the programs of study, needs, academic endeavor and versatility [11].

Shaqour and Daher [12] found that the use of electronic resources by the students had positive relationship with the provision of the electronic resources. They also identified that the use of electronic resources depend on the course requirements and resource characteristics. Emwanta and Nwalo [13] studied the influence of computer literacy and subject background on the use of electronic resources by undergraduate students. They identified that the computer literacy and subject background had significant impact on using electronic information resources by the students.

Singh et al [14] studied the factors influencing the use of electronic resources by the international students. Their study identified that the factors affecting the use of electronic information services were the study level, English proficiency and computer skills. Downes [15] discussed benefits of open educational resources. He discussed about the sustainability of open educational resources in terms of funding models, technical models and content models.

Ebersole [16] studied the web usage with respect to duration of usage, purpose of use, level of study of students to identify the student's academic use. He identified the effective use of the rich resources provided via the web is complicated by a number of intervening variables. Maughan [17] had studied on cross disciplinary use and satisfaction of graduate student. He identified that all the respondents, regardless of academic discipline, consulted a smaller range of materials.

McDowell identified that the fast growing array of electronic information resources is often viewed as a significant opportunity for change in education. He had suggested that the students need to develop the capabilities to deal with the information [18]. Though various studies have been conducted with respect to measure the impacts of different factors on using electronic online resources, no such studies could be found with respect to specializations / program impacts. There is no existing researches clarify such impacts in particular in Middle East learning environment.

\section{RESEARCH METHODOLOGY}

A questionnaire was prepared and distributed to the respondents studying in Sur University College at various levels under different specializations for measuring the factors influencing users' satisfaction by the same author. The questionnaire contained various research segments that shall be applied in future. The segment related to demographic profile of the respondents, internet resource usage strategies, purposes and methods were considered for this research purposes. The questionnaire had 8 questions related to the demographic profile of the respondents, 4 questions related to this research objective and 2 questions related to general assistance and type of resource the respondents prefer to use in their learning processes.

\subsection{Statistical Analyses and Results}

For this research, primary data were collected from the respondents using the questionnaire. Various statistical analyses were analyzed for finding the impact of specialization on the factors [19]. As the factors had different number of sub-criteria, to find the relationship and impacts probabilistic approach had been selected. Individual probabilities and conditional probabilities were found with respect to the factors and the specializations. Decision tree had been drawn to find the highest impact variable and ranking the variable impact. The sample size 
was $\mathrm{n}=350$. The Cornbach's Alpha reliability was conducted to find the reliability of the data which showed the value 0.8944 .

\subsection{Demographic Analysis}

The demography's of the respondents were analyzed with respect to the various demographic factors. Table 1 shows the age profile of the respondents.

Table 1: Age Profile of the Respondents

\begin{tabular}{|c|c|}
\hline Age & Number of Respondents \\
\hline Less than 20 & 135 \\
\hline $21-30$ & 201 \\
\hline $31-40$ & 10 \\
\hline $41-50$ & 4 \\
\hline Total & 350 \\
\hline
\end{tabular}

In the total number of respondents 303 respondents were single and 47 respondents were married. Fig 1 shows the respondent's gender category. Out of 350 students, 313 students were studying in morning regular mode and 37 students were studying evening mode. 205 students were concentrating only in studies and thus they were not working anywhere. 92 respondents were working in government sector. 39 respondents were working in private sector and 14 respondents were doing their own business.

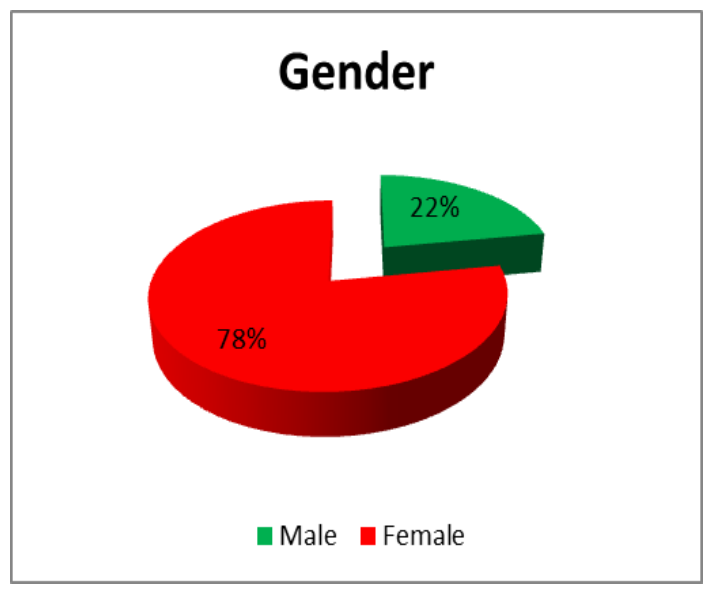

Fig 2: Gender Analysis of Respondents

176 students were living in city, 70 students were living in town area and 104 students were living in villages. $61 \%$ of the respondents said that they prefer to use free internet resources for their learning processes. $19 \%$ of the respondents preferred paid resources whereas $20 \%$ of the respondents preferred to use the internet resources available in the learning resources center provided by the college. Figure 3 show the people assist the students in acquiring required information from the internet resources.

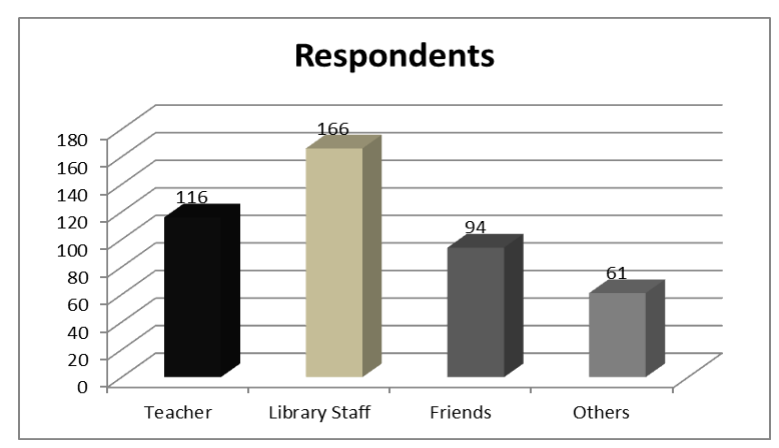

Fig 3: Information Retrieval Assistance

\subsection{Specializations \& Factors: Analysis \& Interpretations}

Table 2 shows the respondents study profile with respective specializations and level of study.

Table2: Respondents Study Profile

\begin{tabular}{|c|c|c|c|c|c|c|c|}
\hline $\begin{array}{c}\text { Level/ } \\
\text { Specialization }\end{array}$ & IT & IS & Acc & FB & MM & $\begin{array}{c}\text { Eng } \\
\mathrm{n}\end{array}$ & $\begin{array}{c}\text { Tota } \\
1\end{array}$ \\
\hline Foundation & 7 & 17 & 5 & 2 & 6 & 21 & 58 \\
\hline Diploma & 55 & 27 & 17 & 17 & 39 & 12 & 167 \\
\hline Bachelor & 48 & 30 & 12 & 8 & 27 & 0 & 125 \\
\hline Total & 110 & 74 & 34 & 27 & 72 & 33 & 350 \\
\hline
\end{tabular}

The above table shows that $16.6 \%$ of the respondents were studying foundation, $47.7 \%$ respondents were studying diploma level and $35.7 \%$ respondents were at bachelor level of their studies. As the college has more number of admissions IT, IS and MM specializations, the corresponding number of respondents from those specializations are comparatively higher than the other specialization. Due to the variations in the student's strengths, the author used probabilistic approach to find the impacts.

\section{Probabilities of the Specializations}

The general probability rule was applied to find the probabilities of the individual specializations. $P\left(S_{i}\right)=\frac{n\left(\mathrm{~S}_{i}\right)}{n(\mathrm{R})}, \mathrm{i}=1$ to 6 Where $\mathrm{n}\left(\mathrm{S}_{\mathrm{i}}\right)$ is total number of respondents in the particular specialization and $n(R)$ is the total number of respondents. Thus, Table 3 shows the probabilities of the specializations with respect to the total number of students. To get the most precision values, probabilities were truncated to 3 digits.

Table 3: Specialization Probability Values

\begin{tabular}{|c|c|c|c|c|c|c|}
\hline $\begin{array}{c}\text { Level/ } \\
\text { Specialization }\end{array}$ & IT & IS & Acc & FB & MM & Engn \\
\hline $\mathrm{P}\left(\mathrm{S}_{\mathrm{i}}\right)$ & 0.314 & 0.211 & 0.097 & 0.077 & 0.206 & 0.094 \\
\hline
\end{tabular}




\subsection{Specialization Impacts on Frequency of Usage}

The questionnaire contained a question related to the frequency of using the internet resources by the learners in their learning processes. The learning processes require different resources assistance in the day - to - day learning activities. But, based on the requirements learners shall use the online resources in their learning activities: Daily, Weekly, Monthly and Hardly Sometimes. To measure the impact of the specializations on these frequency of usages have been studied using conditional probabilities.

$\mathrm{P}_{1}\left(\mathrm{~F}_{\mathrm{i}}\right)=$ Probability of the Frequency with respect to total number of respondents from the particular specialization. Thus,

$$
P_{1}\left(F_{i}\right)=\frac{n\left(F_{i}\right)}{n(S T)}, i=1,2,3,4
$$

$\mathrm{P}_{2}\left(\mathrm{~F}_{\mathrm{i}}\right)=$ Probability of Frequency with respect to the total number of respondents. Thus,

$$
P_{2}\left(F_{i}\right)=\frac{n\left(F_{i}\right)}{n(R)}, i=1,2,3,4
$$

$\mathrm{P}\left(\mathrm{F}_{\mathrm{i}} / \mathrm{S}_{\mathrm{j}}\right)=$ Probability of Frequency of Usage $=\mathrm{P}_{1}\left(\mathrm{~F}_{\mathrm{i}}\right) *$ $\mathrm{P}_{2}\left(\mathrm{~F}_{\mathrm{i}}\right), \mathrm{i}=1,2,3,4 ; \mathrm{j}=1$ to 6 .

Table 4 shows the conditional probabilities of the frequency of usage with respect to the corresponding specializations.

\begin{tabular}{|c|c|c|c|c|c|c|}
\hline $\begin{array}{c}\text { Frequenc } \\
\text { y / } \\
\text { Specializa } \\
\text { tion }\end{array}$ & IT & IS & Acc & FB & MM & Engn \\
\hline $\begin{array}{l}\text { Hardly } \\
\text { Sometime } \\
\text { s }\end{array}$ & $\begin{array}{c}0.004 \\
4\end{array}$ & $\begin{array}{c}0.004 \\
7\end{array}$ & $\begin{array}{c}0.006 \\
8\end{array}$ & $\begin{array}{c}0.003 \\
8\end{array}$ & $\begin{array}{c}0.007 \\
8\end{array}$ & $\begin{array}{c}0.007 \\
0\end{array}$ \\
\hline Monthly & $\begin{array}{c}0.007 \\
5\end{array}$ & $\begin{array}{c}0.003 \\
1\end{array}$ & $\begin{array}{c}0.003 \\
0\end{array}$ & $\begin{array}{c}0.003 \\
8\end{array}$ & $\begin{array}{c}0.004 \\
8\end{array}$ & $\begin{array}{c}0.000 \\
0\end{array}$ \\
\hline Weekly & $\begin{array}{c}0.070 \\
2\end{array}$ & $\begin{array}{c}0.032 \\
5\end{array}$ & $\begin{array}{c}0.003 \\
0\end{array}$ & $\begin{array}{c}0.006 \\
8\end{array}$ & $\begin{array}{c}0.038 \\
1\end{array}$ & $\begin{array}{c}0.003 \\
1\end{array}$ \\
\hline Daily & $\begin{array}{c}0.020 \\
4\end{array}$ & $\begin{array}{c}0.024 \\
1\end{array}$ & $\begin{array}{c}0.014 \\
2\end{array}$ & $\begin{array}{c}0.005 \\
2\end{array}$ & $\begin{array}{c}0.010 \\
2\end{array}$ & $\begin{array}{c}0.028 \\
1\end{array}$ \\
\hline Average & $\begin{array}{c}0.025 \\
6\end{array}$ & $\begin{array}{c}0.016 \\
1\end{array}$ & $\begin{array}{c}0.006 \\
8\end{array}$ & $\begin{array}{c}0.004 \\
9\end{array}$ & $\begin{array}{c}0.015 \\
2\end{array}$ & $\begin{array}{c}0.009 \\
5\end{array}$ \\
\hline
\end{tabular}

Table 4: Conditional Probability of Frequency / Specialization

The overall averages of the specializations were found to measure the impact levels. Based on the average of specializations, it is clear that IT is the highest stimuli of frequency of usage of internet resources whereas FB is the least stimuli of frequency.

\subsection{Specialization Impact on Place of Search}

The World Wide Web provides various places for information storage, dissemination and retrieval as tools. The learners should know the purpose of each of these places and contents of these places. The learner should decide the appropriate place of search that will provide them the correct, reliable and updated information quickly. Such 11 major places were identified for this research purpose and the respondents were asked to select the places where they search and retrieve information in their learning processes.

$\mathrm{P}_{1}\left(\mathrm{PS}_{\mathrm{i}}\right)=$ Probability of place of search with respect to specialization total.

$$
P_{1}\left(\mathrm{PS}_{i}\right)=\frac{n\left(\mathrm{PS}_{i}\right)}{n(\mathrm{ST})}, i=1, \ldots, 11
$$

$\mathrm{P}_{2}\left(\mathrm{PS}_{\mathrm{i}}\right)=$ Probability of place search with respect to total respondents.

$$
P_{2}\left(\mathrm{PS}_{i}\right)=\frac{n\left(\mathrm{PS}_{i}\right)}{n(R)}, i=1, \ldots, 11
$$

$\mathrm{P}\left(\mathrm{PS}_{\mathrm{i}} / \mathrm{S}_{\mathrm{j}}\right)=$ Probability of place of search $=\mathrm{P}_{1}\left(\mathrm{PS}_{\mathrm{i}}\right) *$ $\mathrm{P}_{2}\left(\mathrm{PS}_{\mathrm{i}}\right), \mathrm{i}=1$ to $11, \mathrm{j}=1$ to 6 .

Table 5 shows the conditional probabilities of the place of search. From the above analysis, databases are used by IT students more compared to other specialization students. The students are using general webpages (average $=0.04627$ ) for their information retrieval and knowledge acquisition. Periodicals and blogs are used very less by the Omani learners in their learning processes.

\subsection{Specialization Impact on Purpose of Using Internet Resources}

The internet resources shall be used for different purposes by the learners during their studies. This depends on the learning methods related to the courses they study. 5 major learning processes were identified and the Omani students were asked to state their purpose of using internet resources in their learning processes.

$\mathrm{P}_{1}\left(\mathrm{PU}_{\mathrm{i}}\right)=$ Probability of purpose of use with respect to specialization total.

$$
P_{1}\left(\mathrm{PU}_{i}\right)=\frac{n\left(\mathrm{PU}_{i}\right)}{n(\mathrm{ST})}, i=1, \ldots, 5
$$

$\mathrm{P}_{2}\left(\mathrm{PU}_{\mathrm{i}}\right)=$ Probability of purpose of use with respect to total respondents.

$$
P_{2}\left(\mathrm{PU}_{i}\right)=\frac{n\left(\mathrm{PU}_{i}\right)}{n(R)}, i=1, \ldots, 5
$$

$\mathrm{P}\left(\mathrm{PU}_{\mathrm{i}} / \mathrm{S}_{\mathrm{j}}\right)=$ Probability of place of search $=\mathrm{P}_{1}\left(\mathrm{PU}_{\mathrm{i}}\right) *$ $\mathrm{P}_{2}\left(\mathrm{PU}_{\mathrm{i}}\right), \mathrm{i}=1$ to $5, \mathrm{j}=1$ to 6 .

Table 6 shows the corresponding conditional probabilities of purpose of usage and its average. 
Table 5: Conditional Probabilities on Place of Search

\begin{tabular}{|c|c|c|c|c|c|c|c|}
\hline $\begin{array}{c}\text { Place / } \\
\text { Specialization }\end{array}$ & IT & IS & Acc & FB & MM & Engn & Average \\
\hline Databases & 0.03003 & 0.00386 & 0.00303 & 0.00169 & 0.00571 & 0.00139 & 0.00762 \\
\hline Blogs & 0.00042 & 0.00062 & 0.00034 & 0.00011 & 0.00016 & 0.00078 & 0.00040 \\
\hline Wikis & 0.01623 & 0.00556 & 0.00134 & 0.00381 & 0.00321 & 0.00035 & 0.00508 \\
\hline Journals & 0.00260 & 0.00004 & 0.00134 & 0.00095 & 0.00321 & 0.00009 & 0.00137 \\
\hline Webpages & 0.08145 & 0.06490 & 0.01210 & 0.01788 & 0.05143 & 0.04987 & 0.04627 \\
\hline Search Engines & 0.00374 & 0.00988 & 0.00134 & 0.00381 & 0.00480 & 0.00216 & 0.00429 \\
\hline Digital Libraries & 0.00094 & 0.00386 & 0.00034 & 0.00011 & 0.00036 & 0.00078 & 0.00106 \\
\hline Periodicals & 0.00042 & 0.00004 & 0.00076 & 0.00042 & 0.00099 & 0.00009 & 0.00045 \\
\hline Newspapers & 0.01623 & 0.00869 & 0.00076 & 0.00519 & 0.01286 & 0.00078 & 0.00742 \\
\hline $\begin{array}{c}\text { Educational } \\
\text { Videos }\end{array}$ & 0.00842 & 0.00386 & 0.00412 & 0.00000 & 0.00671 & 0.00139 & 0.00408 \\
\hline Other Sources & 0.01756 & 0.01869 & 0.00210 & 0.00042 & 0.01147 & 0.00554 & 0.00930 \\
\hline Average & 0.01618 & 0.01091 & 0.00251 & 0.00313 & 0.00917 & 0.00575 & 0.00794 \\
\hline
\end{tabular}

Table 6: Conditional Probabilities on Purpose of Usage / Specializations

\begin{tabular}{|c|c|c|c|c|c|c|c|}
\hline Place / Specialization & IT & IS & Acc & FB & MM & Engn & Average \\
\hline Assignment & 0.0935 & 0.0782 & 0.0243 & 0.0238 & 0.0459 & 0.0055 & 0.0452 \\
\hline Homework & 0.0480 & 0.0473 & 0.0054 & 0.0106 & 0.0129 & 0.0031 & 0.0212 \\
\hline Case Study & 0.0115 & 0.0087 & 0.0041 & 0.0038 & 0.0040 & 0.0014 & 0.0056 \\
\hline Project & 0.0318 & 0.0076 & 0.0054 & 0.0004 & 0.0432 & 0.0346 & 0.0205 \\
\hline Exam Preparation & 0.0004 & 0.0006 & 0.0001 & 0.0001 & 0.0002 & 0.0001 & 0.0002 \\
\hline Average & 0.0370 & 0.0285 & 0.0078 & 0.0077 & 0.0212 & 0.0090 & 0.0185 \\
\hline
\end{tabular}

Table 7: Probabilities on Dependency

\begin{tabular}{|l|c|c|c|c|}
\hline $\begin{array}{c}\text { Specialization / } \\
\text { Respondents }\end{array}$ & Respondents & $\begin{array}{c}\text { Probability with } \\
\text { respect to } \\
\text { specialization }\end{array}$ & $\begin{array}{c}\text { Probability with respect } \\
\text { to Total respondents }\end{array}$ & P $\left(\mathrm{D} / \mathrm{S}_{\mathrm{i}}\right)$ \\
\hline IT & $\mathbf{8 1}$ & $\mathbf{0 . 7 3 6}$ & $\mathbf{0 . 2 3 1}$ & $\mathbf{0 . 1 7 0 0}$ \\
\hline IS & $\mathbf{4 9}$ & $\mathbf{0 . 6 6 2}$ & $\mathbf{0 . 1 4 0}$ & $\mathbf{0 . 0 9 2 7}$ \\
\hline Acc & $\mathbf{1 9}$ & $\mathbf{0 . 5 5 9}$ & $\mathbf{0 . 0 5 4}$ & $\mathbf{0 . 0 3 0 2}$ \\
\hline FB & $\mathbf{1 1}$ & $\mathbf{0 . 4 0 7}$ & $\mathbf{0 . 0 3 1}$ & $\mathbf{0 . 0 1 2 6}$ \\
\hline MM & $\mathbf{3 8}$ & $\mathbf{0 . 5 2 8}$ & $\mathbf{0 . 1 0 8}$ & $\mathbf{0 . 0 5 7 1}$ \\
\hline Engn & $\mathbf{1 8}$ & $\mathbf{0 . 5 4 5}$ & $\mathbf{0 . 0 5 1}$ & $\mathbf{0 . 0 2 7 8}$ \\
\hline Total & $\mathbf{2 1 6}$ & & & \\
\hline
\end{tabular}

From the above table, it is clear that the internet resource usage for examination preparation is negligibly less. IT, IS and MM students use internet resources for preparing their assignments as their mean values are higher than overall assignment average. IT and IS students use internet resources for completing their homework and case studies. MM, Engineering and IT students use internet resources for project preparation. It was observed that case study is also having fewer preferences in using internet resources.

\subsection{Specialization Impacts on Dependency on Internet Resources Usage}

The internet resources provide sufficient information. But the abundantly available information cannot be trusted as it is. The reliability and coverage of the information make the learners to depend on those resources in learning processes. Though various other traditional resources are available, the learners shall depend on any of the resources based on the availability. The Omani learners were asked whether they depend only on internet resources or not. The specialization impacts on this dependency were also analyzed. Table 7 shows the corresponding conditional probabilities of the respondents those who depend only on internet resources.

From the above table it is evident that the Omani learners from IT and IS specializations depend on internet resources fully rather than the other specializations. $59.3 \%$ of the FB specialization students said that they do not depend only on the internet resources for their learning requirements. Most of the business department students and engineering department students suggested that they do not depend only on internet resources. 


\section{FINDINGS}

From the above analyses, it is evident that the specializations have major impacts on the Omani learners' internet resource usages. Table 8 shows the average of consolidated conditional probability of the impact on the Omani learners' usage.

In the table, the probabilities are ranked from highest to lowest. It is clear that, IT had scored $1^{\text {st }}$ rank in all the four factors. Thus it shall be assumed to have highest impact. In the same, IS had scored $2^{\text {nd }}$ rank and has the second highest impact. MM had scored the $3^{\text {rd }}$ rank. When we compare the other specializations, the ranking orders are not same in all the four cases. Thud to find the correct order of impact, decision tree had been drawn.
For constructing the decision tree, probabilities of individual factors with respect to the corresponding totals have been found. Then the average of each specialization had been found. Overall average of the specialization of each factor had been taken as the probability of the corresponding factor. Decision tree is shown in fig 4.

Based on the decision tree probabilities, it shall be concluded that the Information Technology specialization has the maximum impact on all the four factors. Information Systems specialization had the second position in impacting the Omani learners to use internet resources in their learning processes. Marketing and Management specialization has the third highest impact on these factors. Accounting specialization has the fourth rank in the impact. Engineering specialization has the fifth level of impact whereas the Finance and Banking specialization has the least impact.

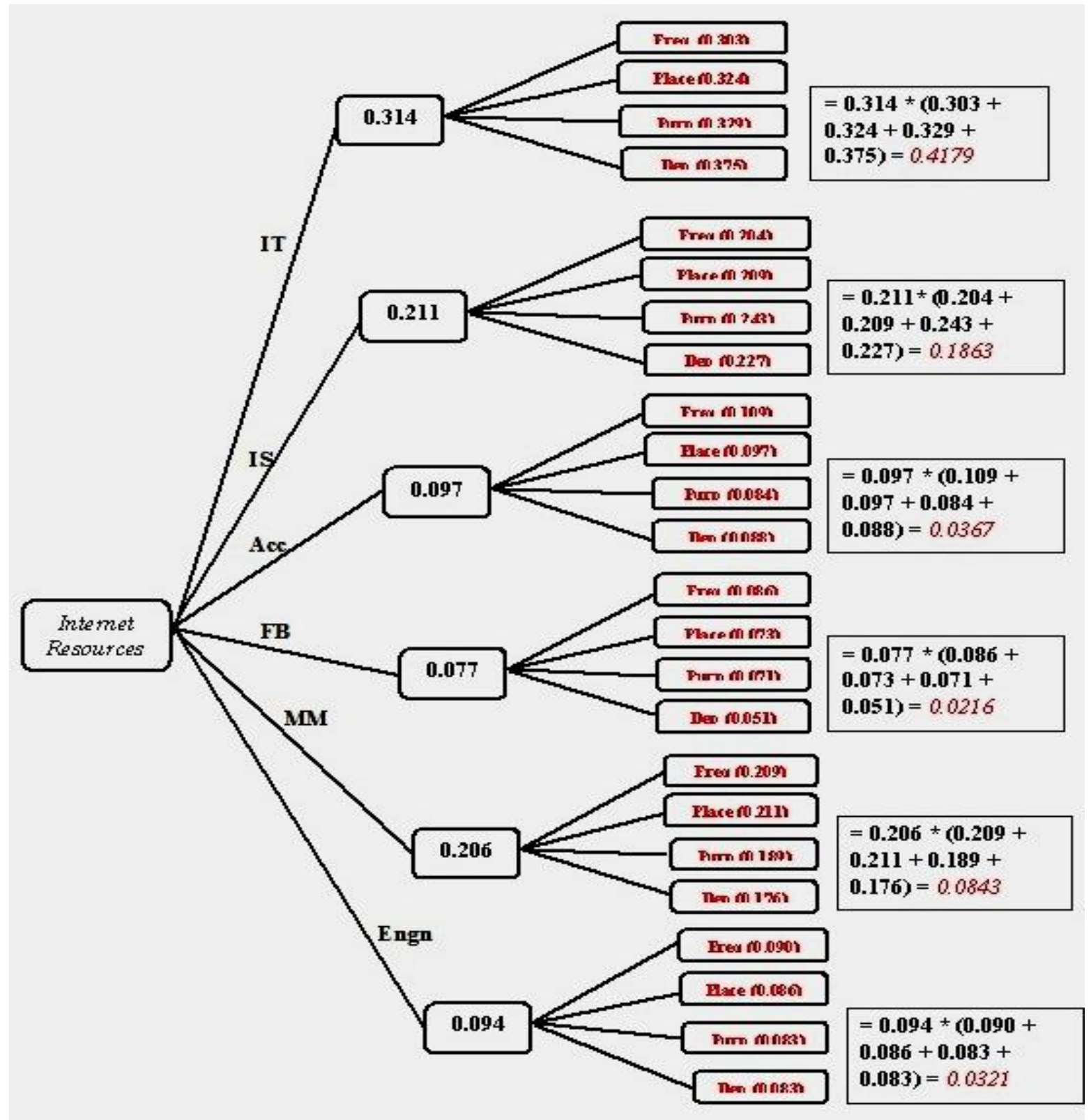

Fig 4: Decision Tree 
Table 8: Consolidated Probabilities and Ranks

\begin{tabular}{|c|c|c|c|c|c|c|c|c|c|c|c|c|}
\hline Specialization & \multicolumn{3}{|c|}{ Frequency of Usage } & \multicolumn{3}{|c|}{ Place of Search } & \multicolumn{3}{|c|}{ Purpose of Usage } & \multicolumn{3}{|c|}{$\begin{array}{l}\text { Dependency on } \\
\text { Resource }\end{array}$} \\
\hline & $\mathrm{P}\left(\mathrm{F}_{\mathrm{i}} / \mathrm{S}_{\mathrm{i}}\right)$ & Rank & Level & $\mathrm{P}\left(\mathrm{PS}_{\mathbf{i}} / \mathrm{S}_{\mathrm{i}}\right)$ & Rank & Level & $\mathrm{P}\left(\mathrm{PU}_{\mathrm{i}} / \mathrm{S}_{\mathrm{i}}\right)$ & Rank & Level & $\mathrm{P}\left(\mathrm{D} / \mathrm{S}_{\mathrm{i}}\right)$ & Rank & Lerel \\
\hline IT & 0.0256 & 1 & High & 0.01618 & 1 & High & 0.0370 & 1 & High & 0.1700 & 1 & High \\
\hline IS & 0.0161 & 2 & High & 0.01091 & 2 & High & 0.0285 & 2 & $\mathrm{High}$ & 0.0927 & 2 & High \\
\hline Acc & 0.0068 & 5 & Low & 0.00251 & 6 & Low & 0.0078 & 5 & Low & 0.0302 & 4 & Low \\
\hline FB & 0.0049 & 6 & Low & 0.00313 & 5 & Low & 0.0077 & 6 & Low & 0.0126 & 6 & Low \\
\hline MM & 0.0152 & 3 & High & 0.00917 & 3 & High & 0.0212 & 3 & High & 0.0571 & 3 & Low \\
\hline Engn & 0.0095 & 4 & Low & 0.00575 & 4 & Low & 0.0090 & 4 & Low & 0.0278 & 5 & Low \\
\hline $\begin{array}{l}\text { Overall } \\
\text { Average }\end{array}$ & 0.0130 & & & 0.00794 & & & 0.0185 & & & 0.0651 & & \\
\hline
\end{tabular}

\section{CONCLUSION}

The above analyses and results showed the impact of specialization that a learner belongs to, on their internet resource usages in the learning processes. It is obviously showed that all the specializations have some impacts on the internet resource usage. The online resource usage depends on the availability and basic background on search techniques. The instructors need to guide the students to use the stipulated internet resources to their corresponding course. The learners need to be motivated towards using such technology in the learning processes. Based on the findings the impact model has been proposed in fig 5 .

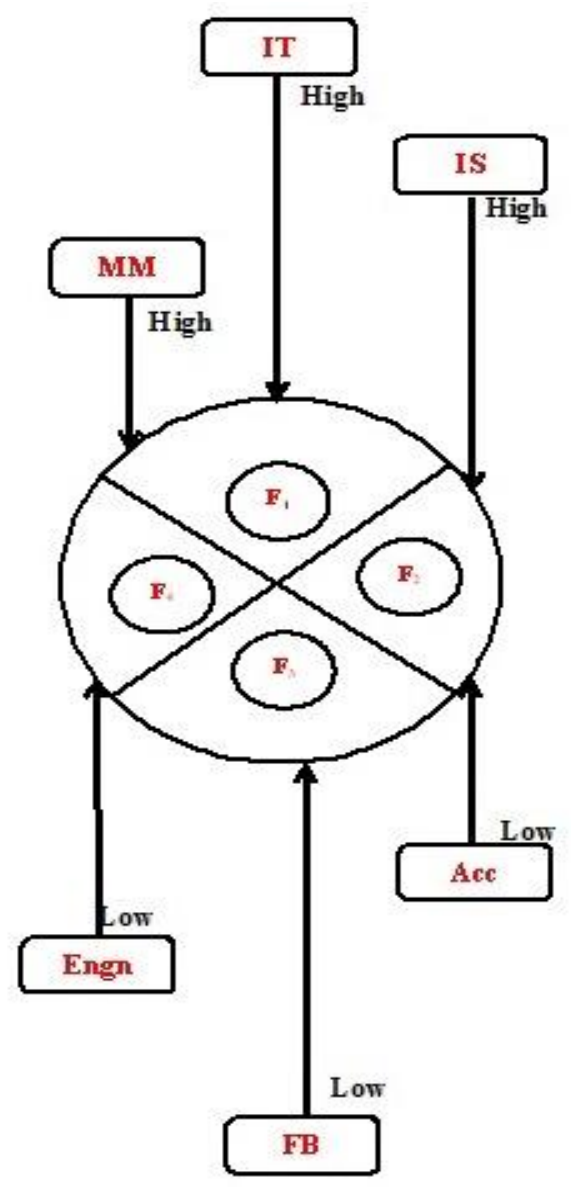

Fig 5: Impact Model of Specialization on Usage

\section{Limitations}

The study has been conducted with available specializations. The results may vary if more specializations have been included. Apart, if the study had been conducted masters' level, the results may vary.

\section{Future Scope}

The specialization impacts on the usage have been conducted in this study. The study may be further extended to measure the impacts of specializations on internet resource usage satisfactions and knowledge acquisition.

\section{ACKNOWLEDGEMENT}

I would like to thank all the participants for their esteemed supports in answering the questionnaire. Also, I would like to thank the dean and Sur University College management for their extensive financial, technical and moral research supports.

\section{REFERENCES}

[1] Ozoemelem, O.A., (2009). Use of Electronic Resources by Post Graduate Students of the Department of Library and Information Science of Delta State University, Abraka, Nigeria. Library Philosophy and Practices. ISSN: 15220222.

[2] Kidd, T. 2002. Electronic journal usage statistics in practice. Serials 15(1): 11-17.

[3] Voorbij, H. J. 1999. Searching scientific information on the Internet: A Dutch academic user survey. Journal of the American Society for Information Science 50 (7): 598-615.

[4] Ray, Kathryn \& Day, Joan (1998). "Student attitudes towards electronic information resources." Information Research, 4(2) Available at: http://informationr.net/ir/42/paper54.html.

[5] Sheard J, Ceddia J, Hurst J (2003). Inferring student learning behaviour from website interactions: A usage analysis. Education and Information Technologies, 8(3), $245-266$.

[6] Holley, R. P. \& Powell, R. R. (2004). Student satisfaction with electronic library resources at Wayne State University. Journal of Access Services, 2(1), 41-62. doi: 10.1300/J204v02n01_06 Available at: http://digitalcommons.wayne.edu/slisfrp/36.

[7] Lamothe. A. R. (2013). Factors Influencing the Usage of an Electronic Book Collection: Size of the eBook 
Collection, the Student Population and the Faculty Population. College \& Research Libraries. Crl301. January 2013. Visited and retrieved on 23.12.2013 from http://crl.acrl.org/content/74/1/39.full.pdf

[8] Mirza, M. S., \& Mahmood, K., (2012). Electronic resources and services in Pakistani university libraries: A survey of users' satisfaction, The International Information $\&$ Library Review (2012), http://dx.doi.org/10.1016/j.iilr.2012.07.00.

[9] Saikia, Mukesh Dr and Gohain, Anjan Mr, "Use and User's Satisfaction on Library Resources and Services in Tezpur University (India): a study" (2013).Library Philosophy and Practice (e-journal).Paper 972. http://digitalcommons.unl.edu/libphilprac/972.

[10] Quadri, G.O., (2013). "Influence of Demographic factors on Use of Online Library Resources by Undergraduate Students in Two Private Nigerian Universities. Library of Philosophy and Practice (e-Journal). Paper 976.

[11] Okiki, O.C., \& Asiru, S.M. (2011). Use of Electronic Information Sources by Postgraduate Students in Nigeria: Influencing Factors. Library Philosophy and Practice. Paper 500.

[12] Shaqour, A., \& Daher, W. (2010). Factors Influencing Students' Use of Electronic Resources and their Opinions About this Use: The Case of Students at An-Najah National University. International Journal Of Emerging Technologies In Learning (IJET), 5(4), pp. 51-58. doi:10.3991/ijet.v5i4.1424.

[13] Emwanta. M. G., \& Nwalo. K.I.N. (2013). Influence of Computer Literacy and Subject Background on Use of Electronic Resources by Undergraduate Students in Universities in South - Western Nigeria. International Journal of Library and Information Science. 5(2). pp: 29 49. DOI: 10.5897/IJLIS12.017.

[14] Singh D, Ogbonnaya CO, Ohakwe J (2011). Factors affecting the use of electronic information services by international students in Malaysia (A Case Study of University of Malasia). Continental Journal of Applied Sciences. 6(3):8-18.

[15] Downes, S. (2007). Models for Sustainable Open Educational Resources. Interdisciplinary Journal of Knowledge and Learning Objects. Volume 3. Pp. 29-34.
[16] Ebersole. S.E. (2005). On Their Own: Student's Academic Use of Commercialized Web. Library Trends. 53(4). pp: $530-538$

[17] Maughan. P.D. (1999). Library Resources and Services: A Cross - Disciplinary Survey of Faculty and Graduate Student Use and Satisfaction. The Journal of Academic Librarianship. 25(5). pp: $354-366$.

[18] McDowell, L. (2002), Electronic information resources in undergraduate education: an exploratory study of opportunities for student learning and independence. British Journal of Educational Technology, 33: 255-266. doi: 10.1111/1467-8535.00261.

[19] Ott, L. \& Longnecker. M. (2001). An Introduction to Statistical methods and Data Analysis. 5 e. Wadsworth Group. ISBN: 0-534-25122-6.

\section{Authors' Profiles}

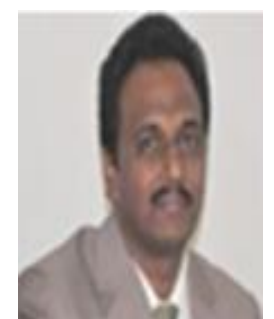

B. Sriram received his Bachelor's degree in Mathematics from St. Joseph's College, Trichirapalli, India and Master's degree in Mathematics from Annamalai University, India. Currently he is working for Sur University College, Sultanate of Oman as lecturer since 2004. He is also holding the position of Quality Assurance Officer since 2009.

He has 21 years of teaching experience in Mathematics and IT courses. He has published 21 research papers in peer reviewed national and international journals and presented 12 papers in national and international conferences and symposiums. He is an active researcher in his work profile (Quality Assurance), teaching areas (Information Systems and Technology) and in specialization (Mathematics and Education).

How to cite this paper: B. Sriram,"Specialization Impact on Internet Resource Usage: Omani Undergraduate Learner's Perspectives", IJMECS, vol.6, no.8, pp.10-17, 2014.DOI: 10.5815/ijmecs.2014.08.02 